\title{
Lanthanum and Manganese Co-Doping Effects on Structural, Morphological, and Magnetic Properties of Sol-Gel Derived $\mathrm{BiFeO}_{3}$
}

\author{
Dovydas Karoblis ${ }^{1}$, Ramunas Diliautas ${ }^{1}$, Kestutis Mazeika ${ }^{2}$ (D), Dalis Baltrunas ${ }^{2}$, Gediminas Niaura ${ }^{2,3}$, \\ Martynas Talaikis ${ }^{4}\left(\mathbb{D}\right.$, Aldona Beganskiene ${ }^{1}$, Aleksej Zarkov ${ }^{1} \mathbb{D}$ and Aivaras Kareiva ${ }^{1, * \mathbb{D}}$ \\ 1 Institute of Chemistry, Vilnius University, Naugarduko 24, LT-03225 Vilnius, Lithuania; \\ dovydas.karoblis@chgf.vu.lt (D.K.); ramunas.diliautas@chgf.stud.vu.lt (R.D.); \\ aldona.beganskiene@chgf.vu.lt (A.B.); aleksej.zarkov@chgf.vu.lt (A.Z.) \\ 2 Center of Physical Sciences and Technology, LT-02300 Vilnius, Lithuania; kestas@ar.fi.lt (K.M.); \\ dalis@ar.fi.lt (D.B.); gediminas.niaura@ftmc.lt (G.N.) \\ 3 Institute of Chemical Physics, Faculty of Physics, Vilnius University, Sauletekio Ave. 3, \\ LT-10257 Vilnius, Lithuania \\ 4 Department of Bioelectrochemistry and Biospectroscopy, Institute of Biochemistry, Life Sciences Center, \\ Vilnius University, LT-10257 Vilnius, Lithuania; martynas.talaikis@gmc.vu.lt \\ * Correspondence: aivaras.kareiva@chgf.vu.lt
}

Citation: Karoblis, D.; Diliautas, R.; Mazeika, K.; Baltrunas, D.; Niaura, G.; Talaikis, M.; Beganskiene, A.; Zarkov, A.; Kareiva, A. Lanthanum and Manganese Co-Doping Effects on Structural, Morphological, and Magnetic Properties of Sol-Gel Derived $\mathrm{BiFeO}_{3}$. Materials 2021, 14 , 4844. https://doi.org/10.3390/ ma14174844

Academic Editor: Michael R. Koblischka

Received: 26 July 2021

Accepted: 23 August 2021

Published: 26 August 2021

Publisher's Note: MDPI stays neutral with regard to jurisdictional claims in published maps and institutional affiliations.

Copyright: (c) 2021 by the authors. Licensee MDPI, Basel, Switzerland. This article is an open access article distributed under the terms and conditions of the Creative Commons Attribution (CC BY) license (https:/ / creativecommons.org/licenses/by/ $4.0 /)$.

\begin{abstract}
In this work, lanthanum and manganese co-substitution effects on different properties of bismuth ferrite solid solutions $\mathrm{Bi}_{1-x} \mathrm{La}_{x} \mathrm{Fe}_{0.85} \mathrm{Mn}_{0.15} \mathrm{O}_{3}$ (x from 0 to 1) prepared by a sol-gel synthetic approach have been investigated. It was observed that the structural, morphological, and magnetic properties of obtained specimens are influenced by the amount of introduced $\mathrm{La}^{3+}$ ions. Surprisingly, only the compound with a composition of $\mathrm{BiFe}_{0.85} \mathrm{Mn}_{0.15} \mathrm{O}_{3}$ was not monophasic, and the presence of neighboring phases was determined from X-ray diffraction analysis and Mössbauer measurements. Structural transitions from orthorhombic to cubic and back to orthorhombic were also observed depending on the $\mathrm{La}^{3+}$ amount. Antiferromagnetic behaviour was observed for all of the samples, with the highest magnetisation values for $\mathrm{Bi}_{0.5} \mathrm{La}_{0.5} \mathrm{Fe}_{0.85} \mathrm{Mn}_{0.15} \mathrm{O}_{3}$. Additionally, structural attributes and morphological features were evaluated by Raman spectroscopy and scanning electron microscopy (SEM), respectively.
\end{abstract}

Keywords: bismuth ferrite; lanthanum ferrite; solid solution; sol-gel processing; antiferromagnetism

\section{Introduction}

Since the work of Spaldin in 2000, where the existence of only a few magnetic ferroelectrics was questioned [1], multiferroics became one of the most investigated topics in the past 20 years. In this type of material, two of the three primary ferroic (ferroelectricity, ferromagnetism, or ferroelasticity) properties coincide in one phase. The combination of magnetism and ferroelectricity are interesting from both theoretical and application point of views. From the practical side, these compounds could be applied in energy-efficient devices [2], photocatalysis [3], biomedicine [4], microwave phase shifter [5], etc. From the theoretical aspect, magnetism arises from partially filled $\mathrm{d}$ or $\mathrm{f}$ shells, while ferroelectricity is associated with the off-centring of different transition metal ions, such as $\mathrm{Ti}^{4+}$, where the $\mathrm{d}$ orbital is empty. Therefore, few mechanisms (lone pair, charge ordering, or "geometric") explaining ferroelectricity are known [6].

Bismuth ferrite $\left(\mathrm{BiFeO}_{3}\right)$ can be considered one of the most investigated perovskitetype multiferroic materials. This compound demonstrates magnetoelectric properties in both thin-film [7] and bulk [8] forms. Nanosized $\mathrm{BiFeO}_{3}$ structures, which display different morphologies, are also explored thoroughly since these nanostructures showed an increase in magnetisation values [9] and better photocatalytic activity [10]. The combination of both 
ferroelectric and (anti)ferromagnetic orders remains a difficult challenge for this compound due to the large leakage current, which arises from high oxygen vacancies concentration, weak magnetoelectric effect, and formation of impurities [11]. Another material, which can display both spontaneous polarisation and magnetisation with magnetoelectric effect, is lanthanum ferrite $\left(\mathrm{LaFeO}_{3}\right)$ [12]. While phase-pure $\mathrm{BiFeO}$ is difficult to prepare, $\mathrm{LaFeO}_{3}$ can be synthesised by different types of techniques, including sol-gel combustion [13], solid-state [14], hydrothermal [15], co-precipitation, or high-energy ball milling [16].

Substitution of A-site, B-site, or both cations can lead to improvement in physical properties or formation of phase-pure $\mathrm{BiFeO}_{3}$. One of the examples can be $\mathrm{La}^{3+}$ intercalation to the $\mathrm{BiFeO}_{3}$ system, leading to an increase in magnetisation, conductivity, and improved ferroelectric properties [17-19]. Substituting $\mathrm{Fe}^{3+}$ ions with $\mathrm{Mn}^{3+}$ ions can lead to structural transition, a better magnetoelectric coupling effect, and enhancement of magnetisation [20-22]. Co-doping with both elements was performed to suppress the formation of oxygen vacancies and $\mathrm{Fe}^{2+}$ ions, which could improve the electrical properties [23]. Furthermore, it was shown that $\mathrm{Bi}_{1-x} \mathrm{La}_{x} \mathrm{Fe}_{1-y} \mathrm{Mn}_{\mathrm{y}} \mathrm{O}_{3} / \mathrm{Ti}_{3} \mathrm{C}_{2}$ hybrids have high catalytic activity towards Congo Red degradation [24]. While most of the studies regarding $\mathrm{Bi}_{1-x} \mathrm{La}_{x} \mathrm{Fe}_{1-y} \mathrm{Mn}_{y} \mathrm{O}_{3}$ focus on intercalation of small amounts of $\mathrm{La}^{3+}$ up to 30\% [25], we aimed to investigate the whole compositional range.

In this work, we prepared a series of $\mathrm{Bi}_{1-x} \mathrm{La}_{x} \mathrm{Fe}_{0.85} \mathrm{Mn}_{0.15} \mathrm{O}_{3}$ (with different $\mathrm{x}$ steps) solid solutions by an environmentally friendly, cost-effective, and simple sol-gel technique using only ethylene glycol as a complexing agent. Various characterisation techniques were used to evaluate structural, morphological, and magnetic properties regarding chemical composition.

\section{Materials and Methods}

For the preparation of $\mathrm{Bi}_{1-x} \mathrm{La}_{x} \mathrm{Fe}_{0.85} \mathrm{Mn}_{0.15} \mathrm{O}_{3}$ solid solutions, bismuth (III) nitrate pentahydrate $\left(\mathrm{Bi}\left(\mathrm{NO}_{3}\right)_{3} \cdot 5 \mathrm{H}_{2} \mathrm{O}\right.$, Roth (Karlsruhe, Germany), 98\%), lanthanum (III) nitrate hexahydrate $\left(\mathrm{La}\left(\mathrm{NO}_{3}\right)_{3} \cdot 6 \mathrm{H}_{2} \mathrm{O}\right.$, Alfa Aesar (Haverhill, MA, USA), 99.9\%), iron (III) nitrate nonahydrate $\left(\mathrm{Fe}\left(\mathrm{NO}_{3}\right)_{3} \cdot 9 \mathrm{H}_{2} \mathrm{O}\right.$, Alfa Aesar, 99.9\%), and manganese (II) nitrate tetrahydrate $\left(\mathrm{Mn}\left(\mathrm{NO}_{3}\right)_{2} \cdot 4 \mathrm{H}_{2} \mathrm{O}\right.$, Alfa Aesar, $\left.99.9 \%\right)$ were used as starting materials. Firstly, required amounts of lanthanum, iron, and manganese nitrates were dissolved in $20 \mathrm{~mL}$ of distilled water. Before addition of bismuth nitrate, the $\mathrm{pH}$ of solution was adjusted to 1 by the addition of nitric acid $\left(\mathrm{HNO}_{3}, 65 \%\right)$. After the dissolution of bismuth nitrate, the complexing agent, ethylene glycol $\left(\mathrm{C}_{2} \mathrm{H}_{6} \mathrm{O}_{2}\right.$, Sigma-Aldrich (St. Louis, $\mathrm{MO}$, USA), $\geq 99.5 \%$ ), was added to the mixture. The molar ratio between total metal ions and ethylene glycol was 1:2. The obtained solution was homogenised under constant stirring at $90^{\circ} \mathrm{C}$ for $1 \mathrm{~h}$. Next, the temperature was increased to $120{ }^{\circ} \mathrm{C}$ for solvent evaporation and the formation of a gel. The resulting gel was dried in the oven at $120^{\circ} \mathrm{C}$ for $6 \mathrm{~h}$, ground in agate mortar, and annealed at $650{ }^{\circ} \mathrm{C}$ with a heating rate of $1^{\circ} \mathrm{C} / \mathrm{min}$ for $1.5 \mathrm{~h}$ in air.

Thermal decomposition of precursor gel was investigated by thermogravimetric and differential scanning calorimetric (TG/DTG-DSC) analysis using PerkinElmer STA 6000 Simultaneous Thermal Analyzer. About $5-10 \mathrm{mg}$ of dried sample was heated from $30{ }^{\circ} \mathrm{C}$ to $900{ }^{\circ} \mathrm{C}$ at $10^{\circ} \mathrm{C} / \mathrm{min}$ heating rate in dry flowing air $(20 \mathrm{~mL} / \mathrm{min})$. X-ray diffraction (XRD) analysis of obtained products was performed with a Rigaku Miniflex II diffractometer using a primary beam $\mathrm{Cu} \mathrm{K} \alpha$ radiation $(\lambda=1.541838 \AA)$. The $2 \theta$ angle of the diffractometer was set in the range from $20^{\circ}$ to $70^{\circ}$ while moving $10^{\circ} / \mathrm{min}$. The obtained diffraction data were refined by the Rietveld method using the Fullprof suite. Crystallite size was calculated by applying Scherrer's equation: $D=\frac{K \lambda}{\beta \cos \theta}$, with the following: K-shape factor (in our case, 0.89 ), $\lambda$-X-ray wavelength, $\beta$-full width at half maximum in radian, $\theta-B$ ragg diffraction angle. The $\beta$ was measured for corundum standard in order to evaluate the instrumental broadening. Alpha FT-IR spectrometer (Bruker, Ettlingen, Germany) was used for FT-IR analysis of compounds. All spectra were recorded at ambient temperature in the range of 4000-400 $\mathrm{cm}^{-1}$. The morphology of samples was examined using a scanning electron microscope (SEM) (Hitachi SU-70, Tokyo, Japan). Raman spectra were acquired 
using LabRam HR800 (Horiba Jobin Yvon, Villeneuve d'Ascq, France) Raman spectrometer equipped with thermoelectrically cooled $\left(-90^{\circ} \mathrm{C}\right) \mathrm{CCD}$ camera (DU920P-BR-DD), 600 lines/mm grating and microscope. Spectra were excited with a $532 \mathrm{~nm}$ beam from the CW diode-pumped solid-state (DPSS) laser (Cobolt Samba, Hübner Photonics, Stockholm, Sweden). The laser power at the sample was restricted to $0.2 \mathrm{~mW}$ to avoid laser-induced sample heating and photodegradation. The $50 \times / 0.50$ NA long working distance (LWD) objective was employed during the measurements. The overall integration time was $600 \mathrm{~s}$. The position of the Raman bands on the wavenumber axis was calibrated by the Si Raman band at $520.7 \mathrm{~cm}^{-1}$. Parameters of the bands were determined by fitting the experimental spectra with Gaussian-Lorentzian shape components using GRAMS / A1 8.0 (Thermo Scientific, Waltham, MA, USA) software. Magnetometer consisting of the lock-in amplifier SR510 (Stanford Research Systems, Sunnyvale, CA, USA), the Gauss/teslameter FH-54 (Magnet Physics) and the laboratory magnet supplied by the power source SM 330-AR-22 (Delta Elektronika, Zierikzee, The Netherlands) was applied to record magnetisation dependences on an applied magnetic field. Mössbauer spectra were measured using ${ }^{57} \mathrm{Co}(\mathrm{Rh})$ source and Mössbauer spectrometer (Wissenschaftliche Elektronik GmbH, Starnberg, Germany). Closed-cycle He cryostat (Advanced Research Systems, Macungie, PA, USA) was applied for low-temperature measurements. The doublets/singlets, sextets, and hyperfine field distributions were used to fit Mössbauer spectra applying WinNormos Site and Dist software. Isomer shift is given relative to $\alpha$-Fe.

\section{Results}

Thermogravimetric analysis was employed to evaluate thermal decomposition behaviour and determine optimum annealing temperature, which is required for the formation of solid solutions. TG/DTG/DSC curves of precursor gel for $\mathrm{Bi}_{0.1} \mathrm{La}_{0.9} \mathrm{Fe}_{0.85} \mathrm{Mn}_{0.15} \mathrm{O}_{3}$ composition compound are presented in Figure 1. Three main degradation steps can be identified from the DTG curve. First, non-significant mass loss (about 3\%) can be observed in the $60-150{ }^{\circ} \mathrm{C}$ temperature range; it can be ascribed to evaporation of adsorbed water. The most significant mass loss (about $46 \%$ ) can be seen in the $160-500{ }^{\circ} \mathrm{C}$ temperature region. This step can be attributed to several processes, including the decomposition of metal nitrates or metal complexes with ethylene glycol and the residual organic part of the gel. Two small exothermic peaks, which are centred around 204 and $280^{\circ} \mathrm{C}$, are the result of a combustion reaction. Final mass loss (about $2 \%$ ) can be seen in the $625-650{ }^{\circ} \mathrm{C}$ range. A similar degradation step previously was observed for La-Fe-O gel and was explained by the decomposition of residual organic compounds [26], ionic carbonates [27], or degradation of amorphous material [28]. From the TG curve, the total mass loss was determined to be $51 \%$, and above $650{ }^{\circ} \mathrm{C}$, the mass remained constant. For this reason, $650{ }^{\circ} \mathrm{C}$ was chosen as a final annealing temperature.

X-ray diffraction analysis was carried out to determine phase purity along with structural changes for the $\mathrm{Bi}_{1-\mathrm{x}} \mathrm{La}_{\mathrm{x}} \mathrm{Fe}_{0.85} \mathrm{Mn}_{0.15} \mathrm{O}_{3}$ solid solutions. The obtained results are demonstrated in Figure 2. Nearly all samples were identified as phase-pure with one exception-pristine $\mathrm{BiFe}_{0.85} \mathrm{Mn}_{0.15} \mathrm{O}_{3}$. It is known that $\mathrm{Fe}^{3+}$ substitution by the small amount of $\mathrm{Mn}^{3+}$ can lead to stabilisation of the perovskite phase while avoiding the formation of neighbouring phases [29]. On the other hand, the annealing temperature, which was used in this work, belongs to the range where $\mathrm{BiFeO}_{3}$ is considered to be metastable with respect to two $\mathrm{Bi}$-rich $\mathrm{Bi}_{25} \mathrm{FeO}_{39}$ sillenite and $\mathrm{Fe}$-rich $\mathrm{Bi}_{2} \mathrm{Fe}_{4} \mathrm{O}_{9}$ mullite phases [30]. Those two impurities phases were observed in our synthesised $\mathrm{BiFe}_{0.85} \mathrm{Mn}_{0.15} \mathrm{O}_{3}$ sample. By intercalating $\mathrm{La}^{3+}$ into the perovskite structure, few trends can be observed in the XRD profiles. The intensity of the peaks labelled (110), (022), and (310) decreases, while the intensity of the (220) peak increases for La-rich solid solutions. Since the ionic radius of the $\mathrm{La}^{3+}$ ion (ionic radius $1.16 \AA$ in VIII-fold coordination) is slightly smaller than the $\mathrm{Bi}^{3+}$ ion (ionic radius $1.17 \AA$ in VIII-fold coordination) [31], only a slight peak shift can be observed in the XRD patterns. 


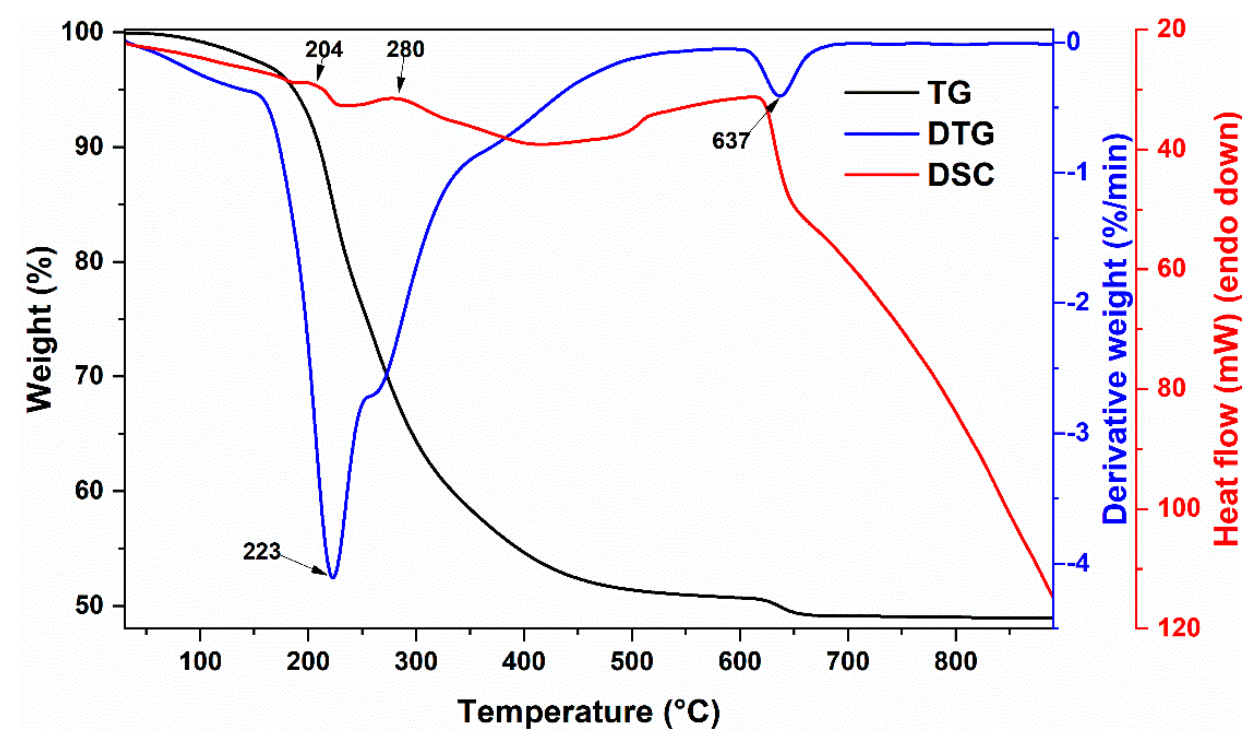

Figure 1. TG/DTG/DSC curves of (0.1)Bi-(0.9)La-(0.85)Fe-(0.15)Mn gel.

Rietveld refinement was carried out for all synthesised solid solution specimens. The splitting of the most intense (200) peak was not observed for any of our samples, which means that the perovskite structure deviates from the crystal symmetry of the $\mathrm{BiFeO}_{3}$ compound, which has a trigonal unit cell with rhombohedral or hexagonal axes. Fitting was performed with various structural models $(R 3 c, P b n m, P m \overline{3} m, R 3 c+P b n m, R 3 c+P m \overline{3} m$, etc.), previously completed by Kumar and Kar [25] for $\mathrm{Bi}_{1-\mathrm{x}} \mathrm{La}_{\mathrm{x}} \mathrm{Fe}_{1-\mathrm{x}} \mathrm{Mn}_{\mathrm{x}} \mathrm{O}_{3}$ (x varying from 0 to 0.3 ) solid solutions. They observed that the structure of all co-doped samples consists of a mixture of two different phases: orthorhombic with Pbnm space group and rhombohedral with $R 3 c$ space group. In our case, the $\mathrm{BiFe}_{0.85} \mathrm{Mn}_{0.15} \mathrm{O}_{3}$ sample has an orthorhombic unit cell with a Pbnm space group. B-site substitution with $\mathrm{Mn}^{3+}$ [32] or $\mathrm{Ga}^{3+}$ [33] ions can lead to identical structural transition. The compound with $10 \% \mathrm{La}^{3+}$ has an identical structure to the $\mathrm{BiFe}_{0.85} \mathrm{Mn}_{0.15} \mathrm{O}_{3}$ sample, with a decrease in cell volume and slight variations in lattice parameters. Further increase in $\mathrm{La}^{3+}$ up to $75 \%$ resulted in a structural change to a cubic unit cell with $P m \overline{3} m$ space group. Moreover, the appearance of new diffractions peaks labelled (111), (211), (221), and (131) for a sample containing $90 \%$ of $\mathrm{La}^{3+}$ confirms another structural transition from cubic to the orthorhombic unit cell with the Pbnm space group. Interestingly, in comparison with the solid solution with $90 \%$ of $\mathrm{La}^{3+}$ ions, the $\mathrm{LaFe}_{0.85} \mathrm{Mn}_{0.15} \mathrm{O}_{3}$ compound has an increase in unit cell parameters and cell volume. Analogous results were observed for $\mathrm{Bi}_{1-x} \mathrm{La}_{x} \mathrm{FeO}_{3}$ solid solutions, where an increase in $\mathrm{La}^{3+}$ concentration resulted in an increase in cell parameters [34]. This was explained by the fact that Bi-containing compounds have a larger quantity of oxygen vacancies because of the lower strength of the $\mathrm{Bi}-\mathrm{O}$ bond.

The most intense diffraction peak (200) was chosen for the calculation of crystallite size. The obtained results are presented in Table 1. Three distinctive regions can be excluded according to the structural transitions observed from XRD patterns. Firstly, the intercalation of $10 \%$ of $\mathrm{La}^{3+}$ leads to a small increase in crystallite size. After the structural change from orthorhombic to cubic unit cell, the crystallite size increased by $25 \%$ in comparison with the previous compound. The compound with $90 \%$ of $\mathrm{La}^{3+}$ showed a sudden decrease in crystallite size, which can be associated with the structural change. Furthermore, $\mathrm{LaFe}_{0.85} \mathrm{Mn}_{0.15} \mathrm{O}_{3}$ showed a similar crystallite size to the $\mathrm{Bi}_{0.25} \mathrm{La}_{0.75} \mathrm{Fe}_{0.85} \mathrm{Mn}_{0.15} \mathrm{O}_{3}$ solid solution. 


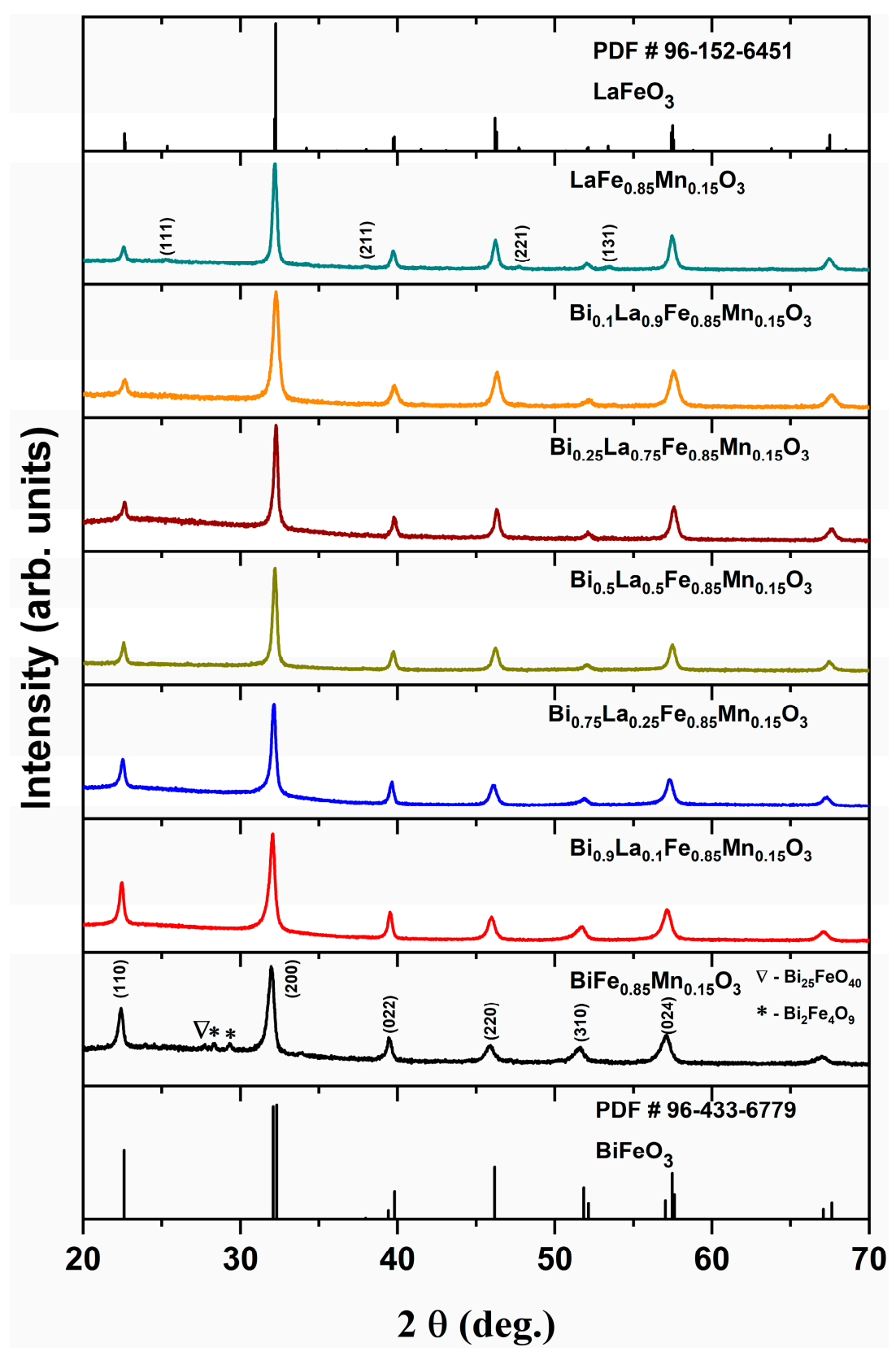

Figure 2. XRD patterns of $\mathrm{Bi}_{1-\mathrm{x}} \mathrm{La}_{x} \mathrm{Fe}_{0.85} \mathrm{Mn}_{0.15} \mathrm{O}_{3}$ samples.

Table 1. Crystallite size for $\mathrm{Bi}_{1-\mathrm{x}} \mathrm{La}_{\mathrm{x}} \mathrm{Fe}_{0.85} \mathrm{Mn}_{0.15} \mathrm{O}_{3}$ solid solutions.

\begin{tabular}{cc}
\hline Formula & D, $\mathbf{n m}$ \\
\hline $\mathrm{BiFe}_{0.85} \mathrm{Mn}_{0.15} \mathrm{O}_{3}$ & 19.18 \\
$\mathrm{Bi}_{0.9} \mathrm{La}_{0.1} \mathrm{Fe}_{0.85} \mathrm{Mn}_{0.15} \mathrm{O}_{3}$ & 20.39 \\
$\mathrm{Bi}_{0.75} \mathrm{La}_{0.25} \mathrm{Fe}_{0.85} \mathrm{Mn}_{0.15} \mathrm{O}_{3}$ & 25.18 \\
$\mathrm{Bi}_{0.5} \mathrm{La}_{0.5} \mathrm{Fe}_{0.85} \mathrm{Mn}_{0.15} \mathrm{O}_{3}$ & 28.72 \\
$\mathrm{Bi}_{0.25} \mathrm{La}_{0.75} \mathrm{Fe}_{0.85} \mathrm{Mn}_{0.15} \mathrm{O}_{3}$ & 29.39 \\
$\mathrm{Bi}_{0.1} \mathrm{La}_{0.9} \mathrm{Fe}_{0.85} \mathrm{Mn}_{0.15} \mathrm{O}_{3}$ & 19.60 \\
$\mathrm{LaFe}_{0.85} \mathrm{Mn}_{0.15} \mathrm{O}_{3}$ & 29.53 \\
\hline
\end{tabular}

The short-range structure of studied compounds was probed by Raman spectroscopy by using a $532 \mathrm{~nm}$ excitation wavelength. The technique is very sensitive to structural distortions and could provide additional structural information on unit cells as well as 
space-group type. Figure 3 compares the Raman spectra of $\mathrm{BiFeO}_{3}$ and $\mathrm{BiFe}_{0.85} \mathrm{Mn}_{0.15} \mathrm{O}_{3}$ samples. $\mathrm{BiFe}_{0.85} \mathrm{Mn}_{0.15} \mathrm{O}_{3}$ was chosen because this compound is known for possessing different structures with a variety of space groups. Pure $\mathrm{BiFeO}_{3}$ exhibits a characteristic pattern of bands related to a rhombohedrically distorted perovskite structure; the main bands are located at $78 \mathrm{~cm}^{-1}$ (symmetry E, band E-1), $141 \mathrm{~cm}^{-1}\left(\mathrm{~A}_{1}-1\right), 173 \mathrm{~cm}^{-1}\left(\mathrm{~A}_{1}-2\right)$, $221 \mathrm{~cm}^{-1}\left(\mathrm{~A}_{1}-3\right), 270 \mathrm{~cm}^{-1}$ (E-3), $348 \mathrm{~cm}^{-1}$ (E-5), $366 \mathrm{~cm}^{-1}$ (E-6), $469 \mathrm{~cm}^{-1}\left(\mathrm{~A}_{1}-5\right)$, and 527 $\mathrm{cm}^{-1}$ (E-8) [29,35-38]. The low-intensity band near $604 \mathrm{~cm}^{-1}$ might be associated with the E-9 mode or related with second-order vibrational transition [38-40]. The $A_{1}$ symmetry bands located at 141,173, and $221 \mathrm{~cm}^{-1}$ and one E symmetry mode located at $78 \mathrm{~cm}^{-1}$ are the most intense features in the spectrum of pure $\mathrm{BiFeO}_{3}$ compound.

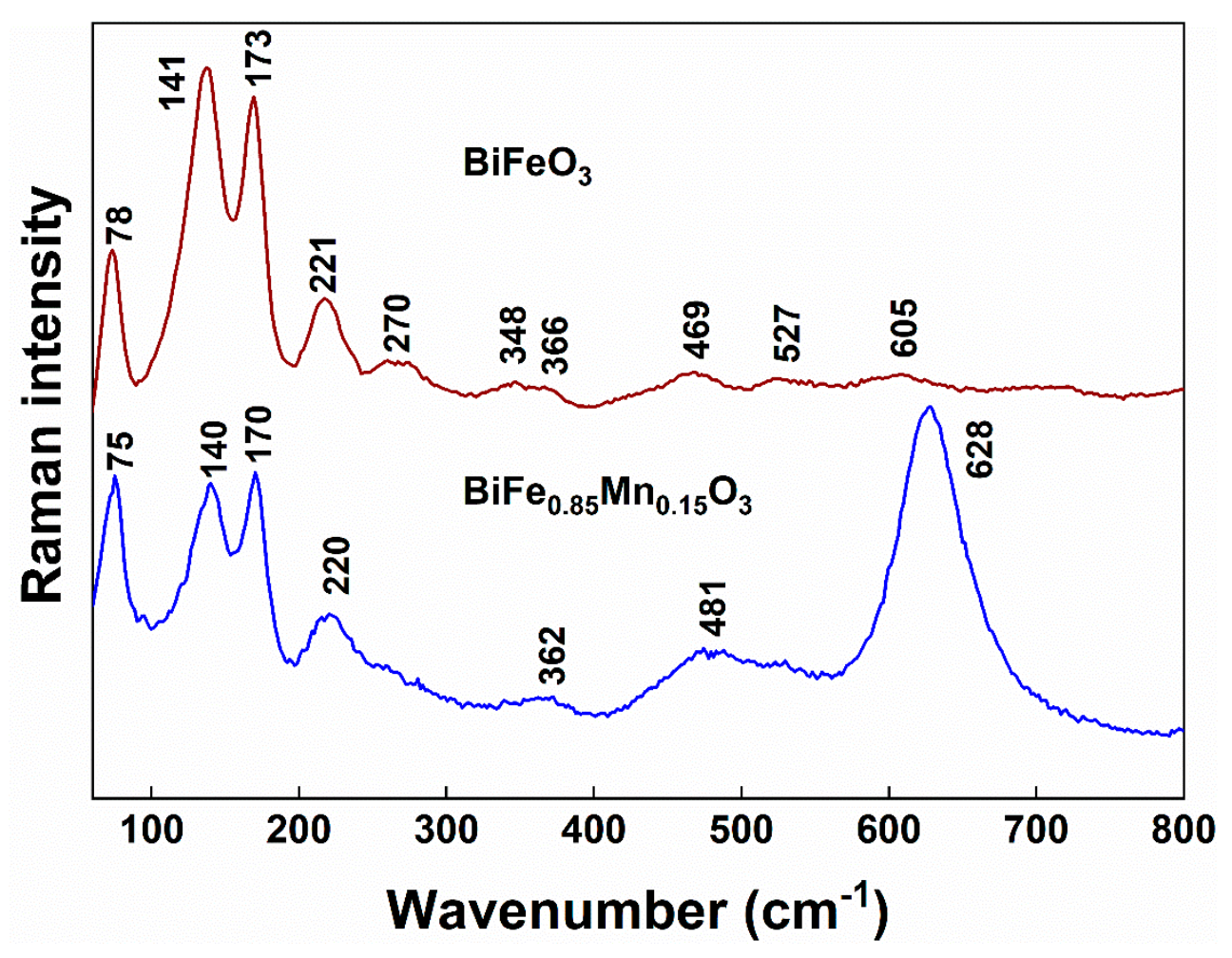

Figure 3. Raman spectra of polycrystalline $\mathrm{BiFeO}_{3}$ and $\mathrm{BiFe}_{0.85} \mathrm{Mn}_{0.15} \mathrm{O}_{3}$ samples in the frequency region of $60-800 \mathrm{~cm}^{-1}$. The excitation wavelength is $532 \mathrm{~nm}(0.2 \mathrm{~mW})$.

Doping with $\mathrm{Mn}^{3+}$ ions results in drastic changes in the Raman spectrum (Figure 3). A strong and relatively broad band appears near $628 \mathrm{~cm}^{-1}$ along with the broad middleintensity feature near $481 \mathrm{~cm}^{-1}$. In contrast, little changes are visible for lower frequency $\mathrm{A}_{1}$ symmetry bands located at 140,170 , and $220 \mathrm{~cm}^{-1}$. These low-frequency modes are mainly related to $\mathrm{Bi}-\mathrm{O}$ stretching vibrations [41,42]. Thus, small spectra changes indicate little perturbation in the $\mathrm{Bi}-\mathrm{O}$ bonding structure after the introduction of $\mathrm{Mn}^{3+}$ ions. The appearance of a strong band near $628 \mathrm{~cm}^{-1}$ indicates $\mathrm{Mn}^{3+}$ ions-induced perturbations in the $\mathrm{Fe}-\mathrm{O}$ bonding range. Indeed, high-frequency E- 8 and E-9 modes earlier were attributed as mainly related to $\mathrm{Fe}-\mathrm{O}$ stretching bands [41,42]. These peaks are sensitive to the tilt of oxygen octahedra [40]. Intensification of a band at $628 \mathrm{~cm}^{-1}$ might be related to the transformation of short-range structure from rhombohedral ( $R 3 c$ space group) to orthorhombic (Pbnm space group) [43]. A similar band was observed for orthorhombic rare-earth manganites $\left(\mathrm{RMnO}_{3}\right)$ (Pnma space group for oxygen octahedra) [44]. These observations confirm the results of the XRD analysis.

FT-IR spectroscopy analysis was carried out to further investigate structural changes in $\mathrm{Bi}_{1-\mathrm{x}} \mathrm{La}_{\mathrm{x}} \mathrm{Fe}_{0.85} \mathrm{Mn}_{0.15} \mathrm{O}_{3}$ solid solutions, and results are demonstrated in Figure 4. In general, the characteristic bands for orthoferrites and orthomanganites can be found in slightly different regions $-600-250 \mathrm{~cm}^{-1}$ and $700-200 \mathrm{~cm}^{-1}$, respectively [45]. In our case, 
no absorption bands were observed in the 4000-600 $\mathrm{cm}^{-1}$ interval, which indicates the absence of residual organic species or carbonates in solid solutions. Our previous study [22] on $\mathrm{BiFe}_{1-\mathrm{x}} \mathrm{Mn}_{\mathrm{x}} \mathrm{O}_{3}$ solid solutions revealed that the addition of $\mathrm{Mn}^{3+}$ could result in the most intense peak shift to higher wavenumbers. Samples with orthorhombic structure have two absorption bands: a strong and sharp band located at $533-552 \mathrm{~cm}^{-1}$ region as well as a weak and broad one at $436-474 \mathrm{~cm}^{-1}$. Only one peak at around $550 \mathrm{~cm}^{-1}$ can be observed for compounds with cubic structures. These bands can be ascribed to the stretching mode of the $\mathrm{Fe}-\mathrm{O}$ bond in the $\mathrm{FeO}_{6}$ octahedra. With the increase of $\mathrm{La}^{3+}$ concentration, weaker absorption band shifts to higher wavenumbers, while a strong intensity peak only shifts to higher wavenumbers until the $\mathrm{La}^{3+}$ amount reaches $50 \%$. Larger substitution results in a monotonic shift to lower wavenumbers. Furthermore, no stretching or bending vibrations belonging to $\mathrm{Bi}_{2} \mathrm{O}_{3}$ or $\mathrm{La}_{2} \mathrm{O}_{3}$ can be visible for all our samples, which indicate no presence of these impurity phases.

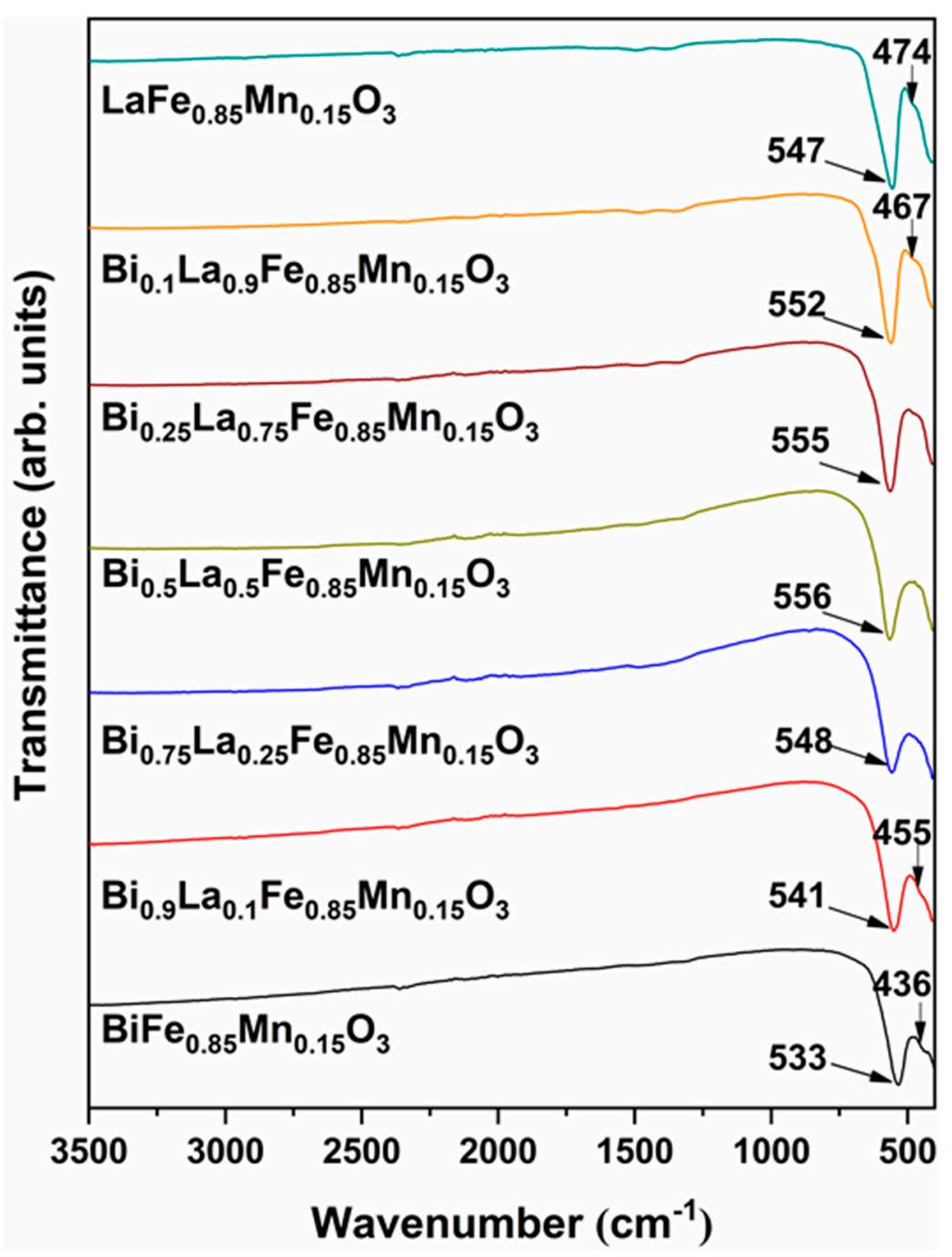

Figure 4. FT-IR spectra of $\mathrm{Bi}_{1-x} \mathrm{La}_{x} \mathrm{Fe}_{0.85} \mathrm{Mn}_{0.15} \mathrm{O}_{3}$ samples.

To investigate the influence of $\mathrm{La}^{3+}$ and $\mathrm{Mn}^{3+}$ co-doping on the morphology of mixedmetal ferrite powders, the SEM analysis was executed for solid solutions of four different compositions, and the results are demonstrated in Figure 5. The $\mathrm{Bi}_{0.9} \mathrm{La}_{0.1} \mathrm{Fe}_{0.85} \mathrm{Mn}_{0.15} \mathrm{O}_{3}$ sample (Figure 5a) consists of particles, which are necked to each other, forming some larger aggregates. Around $90 \%$ of particles for this compound are in the 50-250 nm range. Further increase in $\mathrm{La}^{3+}$ amount up to $25 \%$ resulted in a decrease in particle size (Figure $5 \mathrm{~b}$ ). For this sample, $95 \%$ of particles are in the $20-100 \mathrm{~nm}$ range. The $\mathrm{Bi}_{0.5} \mathrm{La}_{0.5} \mathrm{Fe}_{0.85} \mathrm{Mn}_{0.15} \mathrm{O}_{3}$ sample 
has analogous particle size distribution in comparison with a previous solid solution with $25 \%$ of $\mathrm{La}^{3+}$. With further increase in the concentration of $\mathrm{La}^{3+}$ ions, the particle size also increased, which can be seen in Figure $5 d$. For this $\mathrm{Bi}_{0.1} \mathrm{La}_{0.9} \mathrm{Fe}_{0.85} \mathrm{Mn}_{0.15} \mathrm{O}_{3}$ compound, nearly $92 \%$ of particles are in the $40-240 \mathrm{~nm}$ range. Interestingly, it was shown that an increase in $\mathrm{Bi}^{3+}$ content in $\mathrm{Bi}_{x} \mathrm{La}_{1-x} \mathrm{MnO}_{3+\delta}$ solid solutions could lead to drastic particle growth [46]. On the other hand, our previous study revealed that $\mathrm{Mn}^{3+}$ could act as a particle growth inhibitor, limiting the grain size [22]. The intercalation of $15 \% \mathrm{Mn}^{3+}$ ions limited the effect of particle growth, which could be related to the higher concentration of $\mathrm{Bi}^{3+}$ ions.

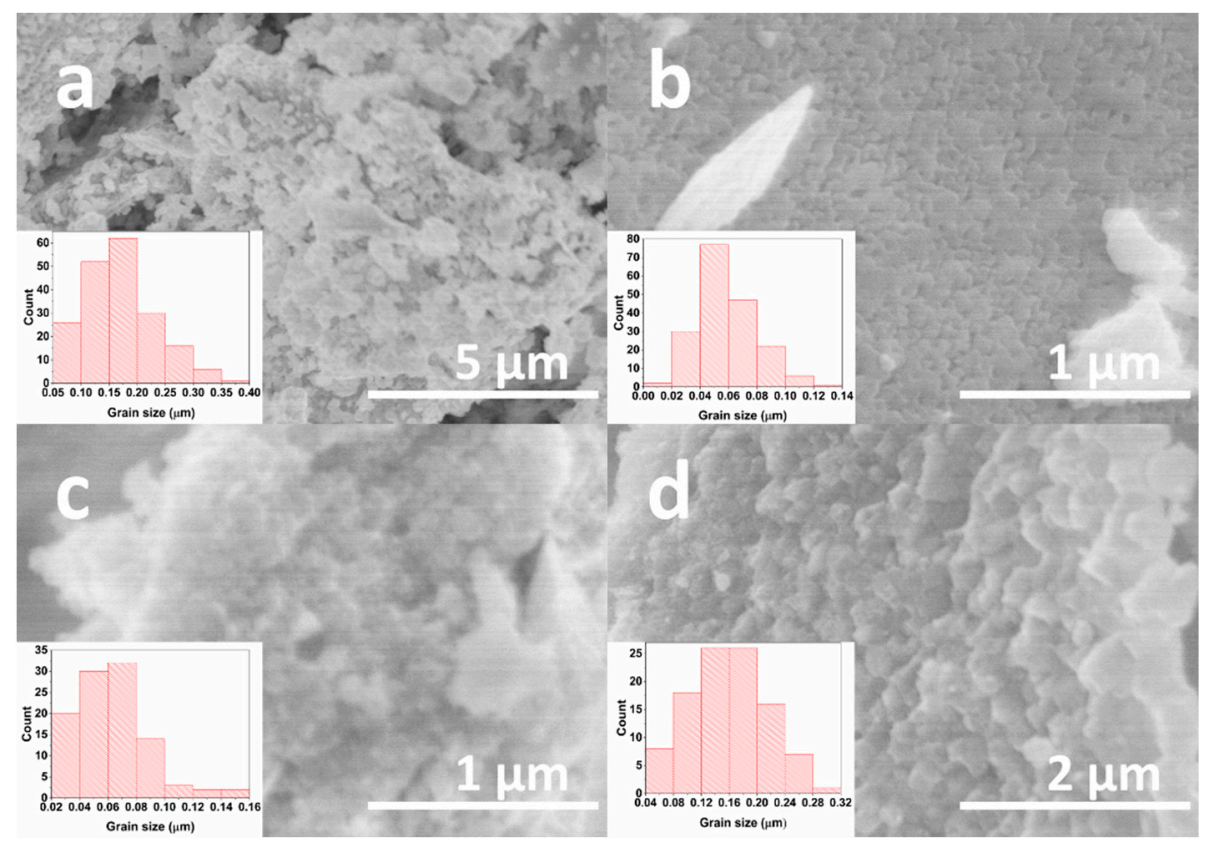

Figure 5. SEM images and grain size distribution of $\mathrm{Bi}_{0.9} \mathrm{La}_{0.1} \mathrm{Fe}_{0.85} \mathrm{Mn}_{0.15} \mathrm{O}_{3}$. (a), $\mathrm{Bi}_{0.75} \mathrm{La}_{0.25} \mathrm{Fe}_{0.85} \mathrm{Mn}_{0.15} \mathrm{O}_{3} \quad$ (b), $\mathrm{Bi}_{0.5} \mathrm{La}_{0.5} \mathrm{Fe}_{0.85} \mathrm{Mn}_{0.15} \mathrm{O}_{3}$ (c) and $\mathrm{Bi}_{0.1} \mathrm{La}_{0.9} \mathrm{Fe}_{0.85} \mathrm{Mn}_{0.15} \mathrm{O}_{3}$ (d) solid solutions.

The linear dependence of magnetisation (Figure 6) is generally consistent with the antiferromagnetic order of spins in samples, but at least for $\mathrm{BiFe}_{0.85} \mathrm{Mn}_{0.15} \mathrm{O}_{3}$, the observed magnetisation is larger than that of bulk $\mathrm{BiFeO}_{3}[47,48]$. It is noteworthy that in the case of nanocrystalline $\mathrm{BiFeO}_{3}$ and $\mathrm{LaFeO}_{3}$ (Table 1), weak ferromagnetism due to uncompensated magnetic moments on the surface of grains can cause an increase in magnetisation [49-51]. However, for $\mathrm{BiFe}_{1-\mathrm{x}} \mathrm{Mn}_{\mathrm{x}} \mathrm{O}_{3}$ solutions, $\mathrm{Mn}$ influences magnetic order, which can cause the formation of additional paramagnetic compounds [22], which cause a decrease in uncompensated magnetisation.

Mössbauer spectra of $\mathrm{Bi}_{1-\mathrm{x}} \mathrm{La}_{x} \mathrm{Fe}_{0.85} \mathrm{Mn}_{0.15} \mathrm{O}_{3}$ samples at room temperature (Figure 7a,b) showed broadened sextet lines, the increased width of which can be mostly related to the substitution of Fe by Mn. However, superparamagnetic relaxation of nanosized grains could also add to the line broadening here. Magnetically split part of spectra was fitted using hyperfine field distribution $\mathrm{P}(B)$ to account for line broadening. At low temperature (Figure $7 \mathrm{~b}$ ), however, the spectra could be fitted to two sextets. The line broadening caused the average hyperfine field $\angle \mathrm{B}>$ (Figure $7 \mathrm{c}$ ) to be lower than the hyperfine field characteristic of $\mathrm{BiFeO}_{3}$ (49-50 T [48]) and $\mathrm{LaFeO}_{3}$ (51.3 T [51]). The parameters of Mössbauer spectra (Figure 7c) slightly depend on the composition of samples. A considerable amount of paramagnetic doublet $\left(\approx 51 \%\right.$ of the spectral area) appeared only for $\mathrm{BiFe}_{0.85} \mathrm{Mn}_{0.15} \mathrm{O}_{3}$. This doublet could be probably attributed to poor crystalline $\mathrm{Bi}_{2} \mathrm{Fe}_{4} \mathrm{O}_{9}$ as isomer shift $\delta=0.31 \pm 0.01 \mathrm{~mm} / \mathrm{s}$ of the doublet is equal to the average isomer shift of two doublets characteristic of $\mathrm{Bi}_{2} \mathrm{Fe}_{4} \mathrm{O}_{9}$ [52]. 


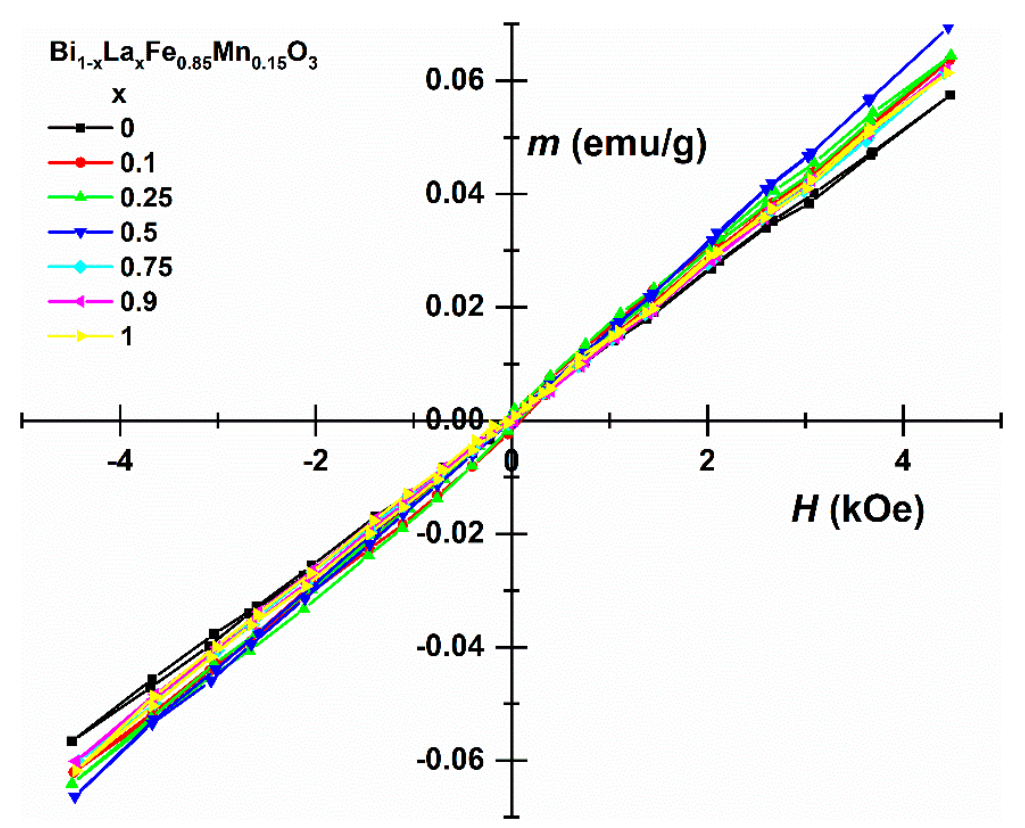

Figure 6. Hysteresis loops of $\mathrm{Bi}_{1-\mathrm{x}} \mathrm{La}_{x} \mathrm{Fe}_{0.85} \mathrm{Mn}_{0.15} \mathrm{O}_{3}$ samples.
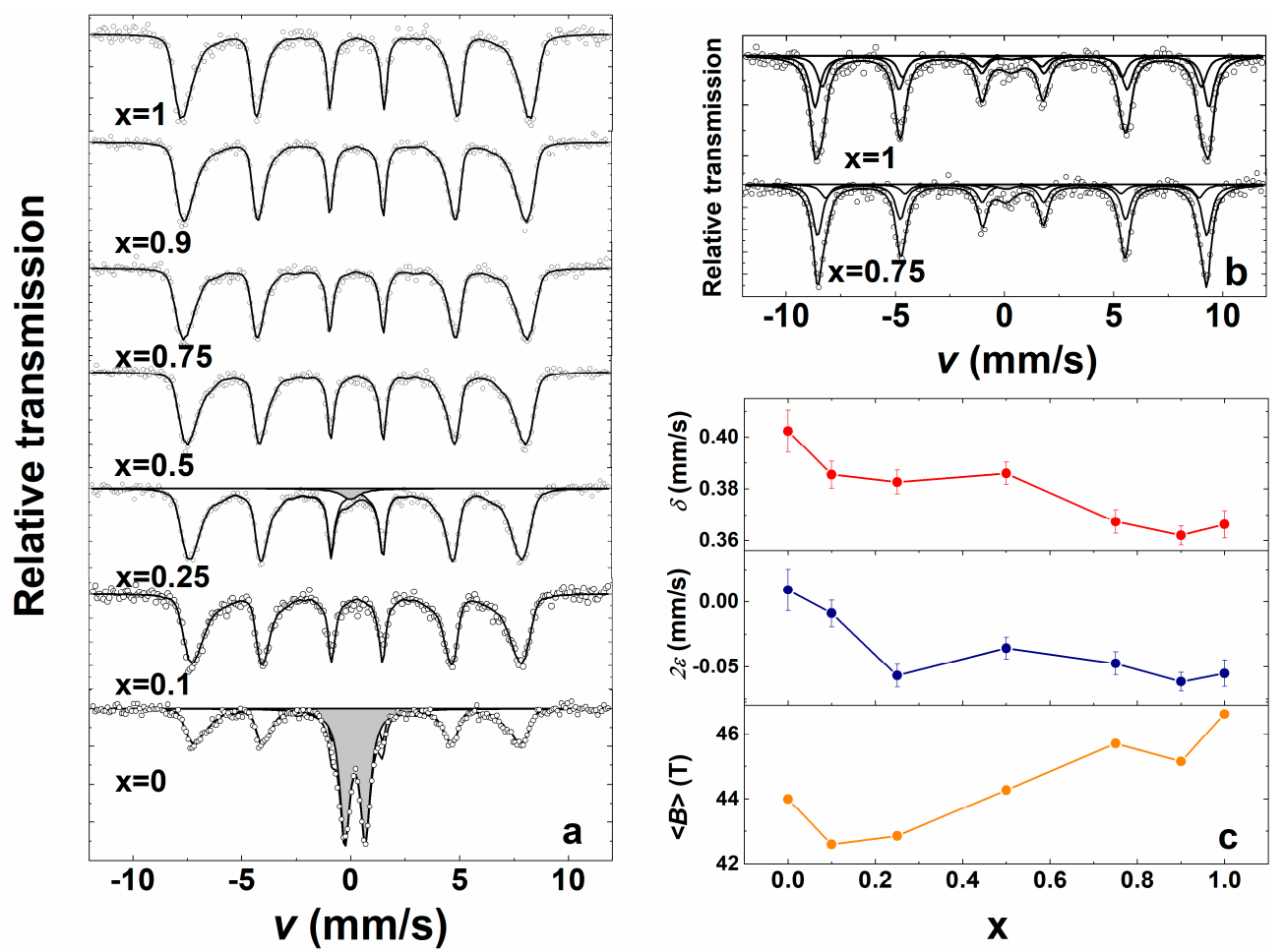

Figure 7. Mössbauer spectra of $\mathrm{Bi}_{1-\mathrm{x}} \mathrm{La}_{\mathrm{x}} \mathrm{Fe}_{0.85} \mathrm{Mn}_{0.15} \mathrm{O}_{3}$ samples at $296 \mathrm{~K}(\mathbf{a})$ and $10 \mathrm{~K}(\mathbf{b})$ and dependence of parameters: isomer shift $\delta$ and quadrupole shift $2 \varepsilon$, and average hyperfine field $<\mathrm{B}>$ of magnetically split part at $296 \mathrm{~K}$ on $\mathrm{x}(\mathrm{c})$.

\section{Conclusions}

An aqueous sol-gel method was successfully applied for the preparation of $\mathrm{Bi}_{1-\mathrm{x}} \mathrm{La}_{\mathrm{x}}$ $\mathrm{Fe}_{0.85} \mathrm{Mn}_{0.15} \mathrm{O}_{3}$ (where $0 \leq \mathrm{x} \leq 1$ ) solid solution specimens. Nearly all compounds were phase-pure, with the exception of $\mathrm{BiFe}_{0.85} \mathrm{Mn}_{0.15} \mathrm{O}_{3}$, where the presence of $\mathrm{Bi}_{2} \mathrm{Fe}_{4} \mathrm{O}_{9}$ and $\mathrm{Bi}_{25} \mathrm{FeO}_{40}$ impurity phases was determined from X-ray diffraction analysis data and Mössbauer measurements. Depending on $\mathrm{La}^{3+}$ concentration, few structural transitions from orthorhombic to cubic and back to orthorhombic were observed in the series. Raman and FT- 
IR spectroscopies also provided additional structural information in good agreement with XRD analysis results. SEM analysis demonstrated that intercalation of $\mathrm{Mn}^{3+}$ ions limited the growth of the particles, and the largest particles were observed for $\mathrm{Bi}_{0.9} \mathrm{La}_{0.1} \mathrm{Fe}_{0.85} \mathrm{Mn}_{0.15} \mathrm{O}_{3}$. All samples demonstrated antiferromagnetic behaviour, with the highest magnetisation values observed for the $\mathrm{Bi}_{0.5} \mathrm{La}_{0.5} \mathrm{Fe}_{0.85} \mathrm{Mn}_{0.15} \mathrm{O}_{3}$ sample.

Author Contributions: Formal analysis, D.K., R.D. and A.Z.; Investigation, D.K., R.D., K.M., D.B., G.N. and M.T.; Resources, A.B. and A.K.; Data curation, D.K. and R.D.; Writing-Original Draft preparation, D.K. and R.D.; Writing-Review and Editing, D.K.; Visualization, D.K., R.D., K.M., D.B., G.N. and M.T.; Supervision, A.Z. and A.K. All authors have read and agreed to the published version of the manuscript.

Funding: This work was supported by a research grant BUNACOMP (No. S-MIP-19-9) from the Research Council of Lithuania.

Conflicts of Interest: The authors declare no conflict of interest.

\section{References}

1. Hill, N.A. Why are there so few magnetic ferroelectrics? J. Phys. Chem. B 2000, 104, 6694-6709. [CrossRef]

2. Manipatruni, S.; Nikonov, D.E.; Lin, C.C.; Gosavi, T.A.; Liu, H.; Prasad, B.; Huang, Y.L.; Bonturim, E.; Ramesh, R.; Young, I.A. Scalable energy-efficient magnetoelectric spin-orbit logic. Nature 2019, 565, 35-42. [CrossRef]

3. Vanga, P.R.; Mangalaraja, R.V.; Ashok, M. Effect of $(\mathrm{Nd}, \mathrm{Ni})$ co-doped on the multiferroic and photocatalytic properties of $\mathrm{BiFeO}_{3}$. Mater. Res. Bull. 2015, 72, 299-305. [CrossRef]

4. Guduru, R.; Liang, P.; Runowicz, C.; Nair, M.; Atluri, V.; Khizroev, S. Magneto-electric nanoparticles to enable field-controlled high-specificity drug delivery to eradicate ovarian cancer cells. Sci. Rep. 2013, 3, 1-8. [CrossRef]

5. Ustinov, A.B.; Srinivasan, G.; Kalinikos, B.A. Ferrite-ferroelectric hybrid wave phase shifters. Appl. Phys. Lett. 2007, 90, 31913. [CrossRef]

6. Khomskii, D. Trend: Classifying multiferroics: Mechanisms and effects. Physics 2009, 2, 20. [CrossRef]

7. Wang, J.; Neaton, J.B.; Zheng, H.; Nagarajan, V.; Ogale, S.B.; Liu, B.; Viehland, D.; Vaithyanathan, V.; Schlom, D.G.; Waghmare, U. $\mathrm{V}$ Epitaxial $\mathrm{BiFeO}_{3}$ multiferroic thin film heterostructures. Science 2003, 299, 1719-1722. [CrossRef] [PubMed]

8. Jia, D.C.; Xu, J.H.; Ke, H.; Wang, W.; Zhou, Y. Structure and multiferroic properties of $\mathrm{BiFeO}_{3}$ powders. J. Eur. Ceram. Soc. 2009, 29, 3099-3103. [CrossRef]

9. Shokrollahi, H. Magnetic, electrical and structural characterization of $\mathrm{BiFeO}_{3}$ nanoparticles synthesized by co-precipitation Powder Technol. 2013, 235, 953-958. [CrossRef]

10. Gao, F.; Chen, X.Y.; Yin, K.B.; Dong, S.; Ren, Z.F.; Yuan, F.; Yu, T.; Zou, Z.G.; Liu, J. Visible-light photocatalytic properties of weak magnetic $\mathrm{BiFeO}_{3}$ nanoparticles. Adv. Mater. 2007, 19, 2889-2892. [CrossRef]

11. Catalan, G.; Scott, J.F. Physics and applications of bismuth ferrite. Adv. Mater. 2009, 21, 2463-2485. [CrossRef]

12. Acharya, S.; Mondal, J.; Ghosh, S.; Roy, S.K.; Chakrabarti, P.K. Multiferroic behavior of lanthanum orthoferrite $\left(\mathrm{LaFeO}_{3}\right) . \mathrm{Mater}$ Lett. 2010, 64, 415-418. [CrossRef]

13. Theingi, M.; Tun, K.T.; Aung, N.N. Preparation, characterization and optical property of $\mathrm{LaFeO}_{3}$ nanoparticles via sol-gel combustion method. SciMedicine J. 2019, 1, 151-157. [CrossRef]

14. Sazelee, N.A.; Idris, N.H.; Din, M.F.M.; Yahya, M.S.; Ali, N.A.; Ismail, M. LaFeO3 synthesised by solid-state method for enhanced sorption properties of MgH2. Results Phys. 2020, 16, 102844. [CrossRef]

15. Zheng, W.; Liu, R.; Peng, D.; Meng, G. Hydrothermal synthesis of LaFeO3 under carbonate-containing medium. Mater. Lett. 2000, 43, 19-22. [CrossRef]

16. Thuy, N.T.; Minh, D. Le Size effect on the structural and magnetic properties of nanosized perovskite $\mathrm{LaFeO}_{3}$ prepared by different methods. Adv. Mater. Sci. Eng. 2012, 2012. [CrossRef]

17. Lee, Y.H.; Wu, J.M.; Lai, C.H. Influence of La doping in multiferroic properties of $\mathrm{BiFeO}_{3}$ thin films. Appl. Phys. Lett. 2006, 88, 42903. [CrossRef]

18. Pandit, P.; Satapathy, S.; Gupta, P.K. Effect of La substitution on conductivity and dielectric properties of $\mathrm{Bi}_{1}-\mathrm{xLaxFeO}_{3}$ ceramics: An impedance spectroscopy analysis. Phys. B Condens. Matter. 2011, 406, 2669-2677. [CrossRef]

19. Yan, X.; Chen, J.; Qi, Y.; Cheng, J.; Meng, Z. Hydrothermal synthesis and characterization of multiferroic Bi1-xLaxFeO 3 crystallites. J. Eur. Ceram. Soc. 2010, 30, 265-269. [CrossRef]

20. Li, Y.; Zhou, S.D.; Zhu, L.; Wang, Y.G. Structural transition and its effect on magnetoelectric coupling in the $\mathrm{BiFe}^{-} \mathrm{xMnxO}_{3}$ ceramics prepared by sol-gel method. J. Magn. Magn. Mater. 2018, 465, 784-788. [CrossRef]

21. Pálová, L.; Chandra, P.; Rabe, K.M. Magnetostructural Effect in the Multiferroic $\mathrm{BiFeO}_{3}-\mathrm{BiMnO}_{3}$ Checkerboard from First Principles. Phys. Rev. Lett. 2010, 104, 37202. [CrossRef] [PubMed]

22. Diliautas, R.; Beganskiene, A.; Karoblis, D.; Mazeika, K.; Baltrunas, D.; Zarkov, A.; Raudonis, R.; Kareiva, A. Reinspection of formation of BiFe1-xMnxO 3 solid solutions via low temperature sol-gel synthesis route. Solid State Sci. 2021, 111, 106458. [CrossRef] 
23. Kolte, J.; Daryapurkar, A.S.; Agarwal, M.; Gulwade, D.D.; Gopalan, P. Effect of substrate temperature on the structural and electrical properties of $\mathrm{La}$ and $\mathrm{Mn}$ co-doped $\mathrm{BiFeO}_{3}$ thin films. Thin Solid Films 2016, 619, 308-316. [CrossRef]

24. Iqbal, M.A.; Ali, S.I.; Amin, F.; Tariq, A.; Iqbal, M.Z.; Rizwan, S. La-and Mn-codoped Bismuth Ferrite/Ti3C2 MXene composites for efficient photocatalytic degradation of Congo Red dye. ACS Omega 2019, 4, 8661-8668. [CrossRef]

25. Kumar, P.; Kar, M. Effect of structural transition on magnetic and dielectric properties of $\mathrm{La}$ and $\mathrm{Mn}$ co-substituted $\mathrm{BiFeO}_{3}$ ceramics. Mater. Chem. Phys. 2014, 148, 968-977. [CrossRef]

26. Chung, S.H.; Chiu, K.C.; Jean, J.H. Preparation and electrical properties of $\mathrm{LaFeO}_{3}$ compacts using chemically synthesized powders. Jpn. J. Appl. Phys. 2008, 47, 8498. [CrossRef]

27. Köferstein, R.; Ebbinghaus, S.G. Synthesis and characterization of nano- $\mathrm{LaFeO}_{3}$ powders by a soft-chemistry method and corresponding ceramics. Solid State Ionics 2013, 231, 43-48. [CrossRef]

28. Liu, T.; Xu, Y. Synthesis of nanocrystalline $\mathrm{LaFeO}_{3}$ powders via glucose sol-gel route. Mater. Chem. Phys. 2011, 129, 1047-1050. [CrossRef]

29. Awasthi, R.R.; Asokan, K.; Das, B. Structural, dielectric and magnetic domains properties of Mn-doped BiFeO 3 materials. Int. J. Appl. Ceram. Technol. 2020, 17, 1410-1421. [CrossRef]

30. Selbach, S.M.; Einarsrud, M.A.; Grande, T. On the thermodynamic stability of $\mathrm{BiFeO}_{3}$. Chem. Mater. 2009, 21, 169-173. [CrossRef]

31. Shannon, R.D. Revised effective ionic radii and systematic studies of interatomic distances in halides and chalcogenides. Acta Crystallogr. Sect. A 1976, 32, 751-767. [CrossRef]

32. Chauhan, S.; Kumar, M.; Chhoker, S.; Katyal, S.C.; Singh, H.; Jewariya, M.; Yadav, K.L. Multiferroic, magnetoelectric and optical properties of $\mathrm{Mn}$ doped $\mathrm{BiFeO}_{3}$ nanoparticles. Solid State Commun. 2012, 152, 525-529. [CrossRef]

33. Gholam, T.; Ablat, A.; Mamat, M.; Wu, R.; Aimidula, A.; Bake, M.A.; Zheng, L.; Wang, J.; Qian, H.; Wu, R. An experimental study of the local electronic structure of B-site gallium doped bismuth ferrite powders. Phys. Lett. A 2017, 381, 2367-2373. [CrossRef]

34. Abdel-Khalek, E.K.; Ibrahim, I.; Salama, T.M.; Elseman, A.M.; Mohamed, M.M. Structural, optical, dielectric and magnetic properties of $\mathrm{Bi1}-\mathrm{xLaxFeO}_{3}$ nanoparticles. J. Magn. Magn. Mater. 2018, 465, 309-315. [CrossRef]

35. Tang, P.; Kuang, D.; Yang, S.; Zhang, Y. Hydrothermal synthesis and the structural, morphologic and magnetic characteristics of Mn doped bismuth ferrite crystallites. J. Mater. Sci. Mater. Electron. 2016, 27, 2594-2600. [CrossRef]

36. Karpinsky, D.V.; Pakalniškis, A.; Niaura, G.; Zhaludkevich, D.V.; Zhaludkevich, A.L.; Latushka, S.I.; Silibin, M.; Serdechnova, M.; Garamus, V.M.; Lukowiak, A. Evolution of the crystal structure and magnetic properties of Sm-doped $\mathrm{BiFeO}_{3}$ ceramics across the phase boundary region. Ceram. Int. 2021, 47, 5399-5406. [CrossRef]

37. Ahlawat, A.; Satapathy, S.; Sathe, V.G.; Choudhary, R.J.; Singh, M.K.; Kumar, R.; Sharma, T.K.; Gupta, P.K. Modification in structure of $\mathrm{La}$ and $\mathrm{Nd}$ co-doped epitaxial $\mathrm{BiFeO}_{3}$ thin films probed by micro Raman spectroscopy. J. Raman Spectrosc. 2015, 46, 636-643. [CrossRef]

38. Yang, Y.; Sun, J.Y.; Zhu, K.; Liu, Y.L.; Wan, L. Structure properties of $\mathrm{BiFeO}_{3}$ films studied by micro-Raman scattering. J. Appl. Phys. 2008, 103, 93532. [CrossRef]

39. Hlinka, J.; Pokorny, J.; Karimi, S.; Reaney, I.M. Angular dispersion of oblique phonon modes in $\mathrm{BiFeO}_{3}$ from micro-Raman scattering. Phys. Rev. B 2011, 83, 20101. [CrossRef]

40. Sharma, P.; Satapathy, S.; Varshney, D.; Gupta, P.K. Effect of sintering temperature on structure and multiferroic properties of Bi0. 825Sm0. 175FeO 3 ceramics. Mater. Chem. Phys. 2015, 162, 469-476. [CrossRef]

41. Thang, D.V.; Hung, N.M.; Khang, N.C.; Oanh, L.T.M. Structural and multiferroic properties of (Sm, Mn) co-doped BiFeO 3 materials. AIMS Mater. Sci. 2020, 7, 160-169. [CrossRef]

42. Yuan, G.L.; Or, S.W.; Chan, H.L.W. Raman scattering spectra and ferroelectric properties of Bi1 $-\mathrm{xNdxFeO3} \mathrm{(x=0-0.2)} \mathrm{multiferroic}$ ceramics. J. Appl. Phys. 2007, 101, 64101. [CrossRef]

43. Pandey, R.; Pradhan, L.K.; Kumar, P.; Kar, M. Double crystal symmetries and magnetic orderings in co-substituted (Y and Mn) bismuth ferrite. Ceram. Int. 2018, 44, 18609-18616. [CrossRef]

44. Martín-Carrón, L.; De Andres, A.; Martínez-Lope, M.J.; Casais, M.T.; Alonso, J.A. Raman phonons as a probe of disorder, fluctuations, and local structure in doped and undoped orthorhombic and rhombohedral manganites. Phys. Rev. B 2002, 66, 174303. [CrossRef]

45. Rao, G.S.; Rao, C.N.R.; Ferraro, J.R. Infrared and Electronic Spectra of Rare Earth Perovskites. Ortho- Chromites, -Manganites and-Ferrites. Appl. Spectrosc. 1970, 24, 436-444. [CrossRef]

46. Karoblis, D.; Mazeika, K.; Baltrunas, D.; Lukowiak, A.; Strek, W.; Zarkov, A.; Kareiva, A. Novel synthetic approach to the

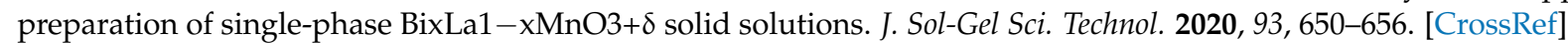

47. Lebeugle, D.; Colson, D.; Forget, A.; Viret, M.; Bonville, P.; Marucco, J.-F.; Fusil, S. Room-temperature coexistence of large electric polarization and magnetic order in $\mathrm{BiFeO}_{3}$ single crystals. Phys. Rev. B 2007, 76, 24116. [CrossRef]

48. Karoblis, D.; Griesiute, D.; Mazeika, K.; Baltrunas, D.; Karpinsky, D.V.; Lukowiak, A.; Gluchowski, P.; Raudonis, R.; Katelnikovas, A.; Zarkov, A. A Facile Synthesis and Characterization of Highly Crystalline Submicro-Sized BiFeO 3 . Materials 2020, $13,3035$. [CrossRef]

49. Huang, F.; Wang, Z.; Lu, X.; Zhang, J.; Min, K.; Lin, W.; Ti, R.; Xu, T.; He, J.; Yue, C. Peculiar magnetism of BiFeO 3 nanoparticles with size approaching the period of the spiral spin structure. Sci. Rep. 2013, 3, 2907. [CrossRef] [PubMed]

50. Lee, W.Y.; Yun, H.J.; Yoon, J.W. Characterization and magnetic properties of $\mathrm{LaFeO}_{3}$ nanofibers synthesized by electrospinning. J. Alloys Compd. 2014, 583, 320-324. [CrossRef] 
51. Sendil Kumar, A.; Manivel Raja, M.; Bhatnagar, A.K. Surface driven effects on magnetic properties of antiferromagnetic $\mathrm{LaFeO}_{3}$ nanocrystalline ferrite. J. Appl. Phys. 2014, 116, 113912. [CrossRef]

52. Papaefthymiou, G.C.; Viescas, A.J.; Le Breton, J.M.; Chiron, H.; Juraszek, J.; Park, T.J.; Wong, S.S. Magnetic and Mössbauer characterization of the magnetic properties of single-crystalline sub-micron sized $\mathrm{Bi}_{2} \mathrm{Fe}_{4} \mathrm{O}_{9}$ cubes. Curr. Appl. Phys. 2015, 15, 417-422. [CrossRef] 